\title{
MULTIDIMENSIONAL ASPECTS OF POVERTY IN BOSNIA AND HERZEGOVINA
}

\author{
Abstract
}

This article explores possibilities for extending the existing standard analyses of poverty in Bosnia and Herzegovina, based on monetary measures of poverty / welfare. Through the investigation of previous and available studies and related databases it is concluded that it is possible to create a new, non-monetary measures of poverty that can be used to determine multidimensional indicators of poverty. The paper proposes two new non-monetary measures of poverty: education and deprivation, which contribute to more accurate assessment and analysis of poverty in the country. On the basis of determined indicators of poverty, based on consumption, education and deprivation, conclusions about the state of poverty in the country and recommendations for the future researches are given.

Keywords: multidimensional poverty indices, poverty, Foster-Greer-Thorbecke's indices, deprivation, educational poverty

\section{INTRODUCTION}

The knowledge about multidimensional nature of poverty is not a new or modern issue. Numerous studies show that the category of poverty is not a purely economic, but a complex social problem with many dimensions and manifestations.

The most common approach to measuring poverty is using monetary measures of poverty/welfare such as income or consumption. Increasingly, poverty is measured through a variety of non-monetary characteristics of the population, such as education, health, food quality, characteristics of housing units, participation in the labor market, political, cultural and other activities, subjective assessments of the status in society, etc.

None of these measures individually provides a complete picture of the situation of poverty in a society. Combining these measures in the common indicators allows obtaining a more complete and accurate picture of the size, nature and causes of poverty in the observed population.

The three most important studies that have dealt with the problem of poverty in Bosnia and Herzegovina are LSMS (Living Standard Measurement Study 2001), HBS 2004 and HBS 2007 (Household Budget Survey 2004 and 2007). As a result of these studies indicators of poverty and inequality were obtained, such as the poverty rate (head count index), poverty gap index, poverty severity index, Gini coefficient, Theil index, Atkinson's measures of inequality and many others. Consumption is conventionally considered a better measure (than income) in transition countries, since it is difficult to estimate the size of income in terms of Bosnian society. Therefore all these measures were calculated using consumption as a measure of

1 M. Sc. Adela Delalić, Senior Teaching Assistant, School of Economics and Business in Sarajevo, University of Sarajevo, BiH, adela.delalic@efsa.unsa.ba 
poverty/welfare. All these indices of poverty and inequality were calculated based on only one measure of poverty - consumption per capita ${ }^{2}$ or adjusted per adult equivalent consumption. ${ }^{3}$

Databases obtained from the HBS 2007 were used as the main source of data for this study. In order to investigate the multidimensional nature of poverty, the main objective was to explore possibilities for determining the poverty indicators that are based on monetary and non-monetary measures of poverty. Also, in anticipation of the next wave of HBS, this paper presents the beginning of the study of poverty in Bosnia and Herzegovina in terms of its multidimensionality.

\section{METHODOLOGY AND DATA OVERVIEW}

The HBS $2007^{4}$ considered was conducted by three statistical institutions in Bosnia and Herzegovina: Agency for Statistics of Bosnia and Herzegovina, Federation of Bosnia and Herzegovina: Federal Office of Statistics and Republika Srpska Institute of Statistics. The sample consisted of 7468 households with 24334 household members. The questionnaire was divided into three parts: Log on procurement, Log on consumption from own production and Final interview. In order to achieve unbiased sample, there were calculated the specific weights for households and individuals and determined sample size considering rate of non-response, based on previous wave of survey (HBS 2004). Household budget survey in B\&H (waves 2004 and 2007) is the most extensive survey conducted in Bosnia and Herzegovina after the war and represents the major source of data for poverty and living standard in B\&H measurement and analysis. The main results were published in two publications: "Household budget survey in B\&H 2007 - Poverty and living conditions" and "Household budget survey in B\&H 2007 - Final results".

Households record expenses for food and beverages and a variety of other goods and services in the Log on procurement for a period of 14 days. Log on consumption from own production is intended to record the estimated value and quantity of goods consumed from own production, in a period of 14 days. The Final interview consists of 11 separate modules, such as demographic characteristics of households and household members, data on housing (the characteristics of housing units, the legal status, housing expenses, etc.), expenditure on furniture, home appliances and services, clothing and footwear and others. Databases collected in the HBS 2007 survey are complex and extensive, and each of them contains over a thousand variables.

Consumption can be treated at the individual and household level. In most cases, consumption at the household level is not a good enough indicator because it does not take into account the differences in size and structure of analyzed households. For the purposes of this

\footnotetext{
2 In these terms, consumption per capita is considered as household consumption divided by number of household members household size.

3 Adjusted consumption per capita equals household consumption divided by adjusted household size. Adjustment of household size was performed using modified OECD equivalence scale. This scale, first proposed by Haagenars (1994), assigns a value of 1 to the household head, of 0.5 to each additional adult member and of 0.3 to each child.

4 The next wave of HBS survey is conducted in 2011. and the first results and databases are expected in 2012.
} 
study, the monetary measure of poverty/welfare included the adjusted per adult equivalent monthly household consumption ${ }^{5}$ and relative poverty line that amounts to $60 \%$ of national consumption median. Previous analyses ${ }^{6}$ of poverty in Bosnia and Herzegovina did not use nonmonetary measures of poverty, nor were combined with monetary measures in order to obtain more precise estimates.

After a thorough search of the questionnaire and databases, in order to analyze the multidimensional nature of poverty in this study, the following non-monetary characteristics of household members were selected and included: education level, characteristics of associated dwelling, possession of household appliances and electronic devices at home and owning a car in the household.

The level of education achieved was used as a separate non-monetary measure. The analysis included only adults (in this case, people aged 15 or more). The following indicator is usually takes as the educational poverty threshold illiteracy or highest achieved level of education, according to ISCED scale, is less than level 2. There were no data on illiteracy in the used databases and the educational level 2 (based on ISCED scale) in the case of the education system in Bosnia and Herzegovina corresponds to primary education. Therefore, for the purposes of this study, the poor in terms of education are those residents who are aged 15 or over and have not completed primary school.

The second non-monetary measure, deprivation, included characteristics of household dwelling (a separate kitchen, bathroom with toilet, running water and electricity), possession of household appliances and electronic devices (electric or gas stove, fridge or freezer or fridge/ freezer, washing machine, cleaning equipment /vacuum cleaner, washing carpets,.../, phone and TV) and owning a car in the household. Variable deprivation was created as follows: based on the above mentioned items, each individual was assigned with the number of items that are missing in the associated household.

The following table contains percentage of deprivation (considering the described items) for household members in Bosnia and Herzegovina.

\footnotetext{
5 Adjusted by use of modified OECD equivalence scale.

6 Household Budget Survey in B\&H 2004, Household Budget Survey in B\&H 2007 and Living Standard Measurement Study in B\&H 2001, performed by Agency for Statistics of Bosnia and Herzegovina, Federation of Bosnia and Herzegovina: Federal Office of Statistics and Republika Srpska Institute of Statistics.
} 
Table 1. Rates (percentages) of lacks of household members in terms of characteristics of housing unit, ownership of household and electronic appliances and automobiles in the household ${ }^{7}$

\begin{tabular}{lcc}
\hline Item & Percentage \\
\hline & Characteristics of household dwelling & $24.7 \%$ \\
Separate kitchen & & $5.7 \%$ \\
Bathroom with toilet & & $5.1 \%$ \\
Running water & & $0.1 \%$ \\
Electricity & Possession of household appliances in household & $8.1 \%$ \\
Electric or gas stove & $1.7 \%$ \\
Fridge, freezer or fridge/freezer & $10.1 \%$ \\
Washing machine & $8.6 \%$ \\
Cleaning equipment (vacuum cleaner, washing carpets,...) & $37.6 \%$ \\
\multicolumn{2}{l}{$\begin{array}{l}\text { Phone } \\
\text { TV }\end{array}$} & Possession of electronic devices in household \\
\hline
\end{tabular}

Source: Author's calculations based on HBS 2007 databases

Table 1 shows that, for example, there are 5.1\% of residents who live in households without running water, $10.1 \%$ in households without a washing machine or $37.6 \%$ in households without a car, in Bosnia and Herzegovina.

Technically, a new variable - deprivation, was designed to assign the number of lacks in associated household to each resident. Table 2 contains the percentages of population with 0,1 , 2 , or more lacks in the associated household.

Table 2. Percentage of population with the certain number of lacks in the associated household ${ }^{8}$

\begin{tabular}{cccc}
\hline No. of lacks & Percentage & $\begin{array}{c}\text { Cumulative percentage } \\
\text { "A certain number" or } \\
\text { more lacks }\end{array}$ \\
0 & $39.0 \%$ & $39.0 \%$ & $100 \%$ \\
1 & $32.9 \%$ & $71.9 \%$ & $61 \%$ \\
2 & $14.1 \%$ & $86.0 \%$ & $28.1 \%$ \\
3 & $5.7 \%$ & $91.7 \%$ & $14 \%$ \\
4 & $3.0 \%$ & $94.7 \%$ & $8.3 \%$ \\
5 & $1.9 \%$ & $96.6 \%$ & $5.3 \%$ \\
6 & $1.4 \%$ & $98.0 \%$ & $3.4 \%$ \\
7 & $1.0 \%$ & $99.0 \%$ & $2 \%$ \\
8 & $0.6 \%$ & $99.6 \%$ & $0.4 \%$ \\
9 & $0.3 \%$ & $99.9 \%$ & $0.1 \%$ \\
10 & $0.1 \%$ & $100.0 \%$ & $0 \%$ \\
11 & $0.0 \%$ & $100.0 \%$ & 0
\end{tabular}

Total $\quad 100.0 \%$

Source: Author's calculations based on HBS 2007 databases

It is estimated that the number of 3 lacks could be considered as the acceptable minimum for the state of serious deprivation in terms of housing quality and standard of living. Specifically, people that live in households with no liquid water are probably in a state of serious deprivation. Such persons probably do not have a bathroom with toilet and washing machine in the associated household (at least 3 lacks) and will be eligible for a state of serious deprivation. Similarly, persons that are living in households without electricity probably live in a household 7 The results are generated by SPSS 17.0, (OSPSS Inc., 2010. 8 The results are generated by SPSS 17.0, (OSPSS Inc., 2010. 
without a TV, electric stoves, vacuum cleaners, etc. (at least 4 lacks), and will also be eligible for a state of serious deprivation. Based on the results presented in Table 2 we conclude that $14 \%$ of the population live in households with 3 or more than 3 lacks. If we take the threshold of 2 lacks, then there are $28.1 \%$ and in case of 4 lacks there are $8.4 \%$ of people in a state of deprivation. Also, based on adjusted per adult equivalent monthly consumption, the percentage of poor people was $18.1 \%$, and we conclude that the threshold of 3 and more than 3 lacks achieves poverty rate closest to the poverty rate based on consumption.

To estimate the one-dimensional and multidimensional poverty measures indices from the Foster-Greer-Thorbecke's family of indices were used.

Foster-Greer-Thorbecke's family of one-dimensional poverty indices is given by the following expression:

$$
P_{\mathrm{a}}=\frac{1}{N} \sum_{i=1}^{n}\left(\frac{z-Y_{i}}{z}\right)^{\mathrm{a}}, \mathrm{a} \geq 0 \text {, }
$$

where:

$\mathrm{N}$ - the total number of residents in the population,

$\mathrm{n}$ - the total number of the poor,

$\mathrm{z}$ - poverty line,

$\mathrm{Y}_{\mathrm{i}}$ - chosen measure of poverty and

a - measure of poverty index sensitivity.

For different values of the parameter a we get different values of Foster-GreerThorbecke's indices. For $\mathrm{a}=0$ we get a headcount index, for $\mathrm{a}=1$ poverty gap index and for $\mathrm{a}=2$ poverty severity index.

Multidimensional indices from Foster-Greer-Thorbecke's family are given by the expression (3.2):

$$
P_{\mathrm{q}}(X, z)=\frac{1}{N} \sum_{j=1}^{m} \sum_{i \in S_{j}} w_{j}\left(1-\frac{x_{i j}}{z_{j}}\right)^{q_{j}},
$$

where:

m - number of poverty measures included

$z_{j}$ - poverty line for j measure (dimension)

$x_{i j}$ - value that person i achieved in terms of $\mathrm{j}$ measure (dimension)

$w_{j}$ - ponder assigned to j measure (dimension)

$\mathbf{q}_{j}$ - measure of index sensitivity in terms of $\mathrm{j}$ measure (dimension)

$S_{j}$ - set of persons that are poor in terms of $\mathrm{j}$ measure (dimension) 
The most used Foster-Greer-Thorbecke's multidimensional poverty indices are: multidimensional headcount index $\left(\mathbf{q}_{j}=0, \forall j=\overline{1, m}\right)$, multidimensional poverty gap index ( $\left.\mathbf{q}_{j}=1, \forall j=\overline{1, m}\right)$ and multidimensional poverty severity index $\left(\mathbf{q}_{j}=2, \forall j=\overline{1, m}\right)$.

For the purpose of this study Foster-Greer-Thorbecke's one-dimensional indices were calculated based on adjusted per adult equivalent monthly consumption, education level and deprivation variable. Two-dimensional Foster-Greer-Thorbecke's were calculated by combining consumption and education level and consumption and deprivation.

In the case of two-dimensional indices based on consumption and deprivation, it was necessary to make certain adjustments to the calculation formula. Specifically, variables consumption and deprivation move in the opposite directions in terms of poverty. When consumption increases then the poverty risk decreases while when deprivation (number of lacks) increases then the poverty risk increases also. Considering that, adjusted expression for calculating the mentioned indices is:

$$
P_{\mathrm{q}}=\frac{1}{N}\left[\sum_{i \in S_{1}} w_{1}\left(\frac{z_{1}-x_{i 1}}{z_{1}}\right)^{\mathrm{q}_{1}}+\sum_{i \in S_{2}} w_{2}\left(\frac{x_{i 2}-z_{2}}{z_{2}}\right)^{\mathrm{q}_{2}}\right],
$$

where the index $j=1$ refers to the consumption and the index $j=2$ to the deprivation.

Generally, headcount index is the simplest, but with some serious drawbacks. It is based just on number of poor and total population size and doesn't consider the intensity and depth of poverty. For example, in two societies of which one have poverty line set at the lower level, headcount index can be equal even though living standard in one of them is significantly lower. The problem of headcount index comparisons can be partly avoided by using relative poverty lines that considers living standard of a certain society. The poverty gap index is more accurate than the headcount index because its sensitivity to the distance from the poverty line. For example, if a poor person becomes poorer, poverty gap index will increase while headcount index stays the same. Due to squaring of the poverty gaps, poverty severity index takes into account individuals that are more distant from poverty line with the greater significance. In this way, this index becomes more sensitive to the changes in the bottom of distribution of income or consumption.

\section{RESULTS}

Calculated one-dimensional and two-dimensional Foster-Greer-Thorbecke's poverty indices, based on adjusted per adult equivalent monthly consumption and deprivation, are shown in Table 3. Indices were calculated at the country level $\left(B \& \mathrm{H}^{9}\right)$ and at the level of its constituent parts $\left(\mathrm{FB} \& \mathrm{H}^{10}, \mathrm{RS}^{11}\right.$ and $\left.\mathrm{BD}^{12}\right)$. In case of the two-dimensional indices, two combinations were calculated: in the first combination, consumption and deprivations were

9 Bosnia and Herzegovina

10 Federation of Bosnia and Herzegovina

11 Republika Srpska

12 Brcko District 
weighted by the same weight (both weights are equal to 0.5), and in the second combination, consumption was weighted by the weight of 0.8 and deprivation was weighted by the weight of 0.2 .

Table 3 .One-dimensional and two-dimensional Foster-Greer-Thorbecke's poverty indices in terms of adjusted per adult equivalent monthly consumption and deprivation ${ }^{13}$

\begin{tabular}{|c|c|c|c|c|c|}
\hline \multirow{2}{*}{ Area } & \multirow{2}{*}{ Index } & \multirow{2}{*}{$\begin{array}{l}\text { One-dim. } \\
\text { Consumption }\end{array}$} & \multirow{2}{*}{$\begin{array}{l}\text { One-dim. } \\
\text { Deprivation }\end{array}$} & \multirow{2}{*}{$\begin{array}{l}\text { Two-dim. } \\
w_{1}=w_{2}=0.5\end{array}$} & \multirow{2}{*}{$\begin{array}{l}\text { Two-dim. } \\
w_{1}=0.8 \mathrm{i} w_{2}=0.2\end{array}$} \\
\hline & & & & & \\
\hline \multirow[t]{3}{*}{ B\&H } & Headcount index & 0.18114 & 0.14032 & 0.16073 & 0.17298 \\
\hline & Poverty gap index & 0.04546 & 0.06922 & 0.05734 & 0.05021 \\
\hline & $\begin{array}{l}\text { Poverty severity } \\
\text { index }\end{array}$ & 0.01725 & 0.07958 & 0.04842 & 0.02972 \\
\hline \multirow[t]{3}{*}{ FB\&H } & Headcount index & 0.16885 & 0.10316 & 0.13601 & 0.15571 \\
\hline & Poverty gap index & 0.04157 & 0.04384 & 0.04270 & 0.04202 \\
\hline & $\begin{array}{l}\text { Poverty severity } \\
\text { index }\end{array}$ & 0.01557 & 0.04565 & 0.03061 & 0.02159 \\
\hline \multirow[t]{3}{*}{$\mathbf{R S}$} & Headcount index & 0.20006 & 0.20578 & 0.20292 & 0.20120 \\
\hline & Poverty gap index & 0.05160 & 0.11812 & 0.08486 & 0.06491 \\
\hline & $\begin{array}{l}\text { Poverty severity } \\
\text { index }\end{array}$ & 0.02007 & 0.14549 & 0.08278 & 0.04515 \\
\hline \multirow[t]{3}{*}{ BD } & Headcount index & 0.25802 & 0.23033 & 0.24417 & 0.25248 \\
\hline & Poverty gap index & 0.06724 & 0.05811 & 0.06268 & 0.06541 \\
\hline & $\begin{array}{l}\text { Poverty severity } \\
\text { index }\end{array}$ & 0.02399 & 0.05519 & 0.03959 & 0.03023 \\
\hline
\end{tabular}

Source: Author's calculations based on HBS 2007 databases

In accordance with the results presented in Table 3, the poverty rate (headcount index) in $\mathrm{B} \& \mathrm{H}, \mathrm{FB} \& \mathrm{H}$ and Brcko District is greater when it is calculated based on consumption than when it is calculated based on deprivation, while in the RS the rates are approximately equal.

On the other hand, in the case of entire B\&H, FB\&H and RS, the depth and severity of poverty, measured by poverty gap and poverty severity index, are greater when they are based on deprivation compared to consumption. Thus, in the case of mentioned areas, the larger part of population is affected by poverty measured by consumption, but that kind of poverty is slighter and more homogeneous than in the case of poverty measured by deprivation.

In the case of $\mathrm{BD}$, the depth of poverty is greater and its strength is lower when the poverty is measured by consumption compared to poverty measured by deprivation.

Some of these conclusions are included in the behavior of multidimensional indices, with different values of the weights. For example, in the case of FB\&H, where the poverty rate measured by consumption is larger than the poverty rate measured by deprivation, with increasing of weight assigned to consumption (from 0.5 to 0.8 ) multidimensional headcount index grows. 
Multidimensional poverty indices, created in this way, can be used as a basis for analyzing poverty in the future. It would be useful to enrich the set of lacks with the intangible dimensions of lacks, such as social or psychological dimension. ${ }^{14}$ In that way, this type of analyses will be deeper and more comprehensive.

Multidimensional poverty indices have often been based on consumption and education. In order to investigate and analyze poverty through these two measures, the onedimensional and two-dimensional poverty indices are determined, based on data from HBS 2004 and HBS 2007. "Educationally poor person" was defined as a person aged 15 or more, who has not completed primary education. In order to compare and combine poverty based on consumption and education, analysis and indices were limited to the population aged 15 or more.

Table 4 shows the values of one-dimensional and two-dimensional Foster-GreerThorbecke's indices (education and consumption), calculated on the basis of data from the HBS 2004 and HBS 2007. The consumption was weighted by the weight of 0.8 and the education was weighted by the weight of 0.2 .

Table $4^{15}$. One-dimensional and two-dimensional headcount index, poverty gap index and poverty severity index in terms of adjusted per adult equivalent monthly consumption and education, based on data from the HBS 2004 and HBS 2007. ${ }^{16}$

\begin{tabular}{|c|c|c|c|c|c|c|c|}
\hline \multirow[t]{3}{*}{ Area } & \multirow[t]{3}{*}{ Index } & \multicolumn{4}{|c|}{ One-dimensional } & \multirow{3}{*}{\multicolumn{2}{|c|}{$\begin{array}{l}\text { Two-dimensional } \\
\boldsymbol{w}_{1}=\mathbf{0 . 8} ; \boldsymbol{w}_{2}=\mathbf{0 . 2}\end{array}$}} \\
\hline & & \multicolumn{2}{|c|}{ Consumption } & \multicolumn{2}{|c|}{ Education } & & \\
\hline & & 2004 & 2007 & 2004 & 2007 & & 2007 \\
\hline \multirow{3}{*}{$\mathrm{B} \& \mathrm{H}$} & Headcount index & 0.18120 & 0.18023 & 0.19668 & 0.20056 & 0.18430 & 0.18429 \\
\hline & Poverty gap index & 0.04335 & 0.04610 & 0.04462 & 0.05245 & 0.04360 & 0.04737 \\
\hline & Poverty severity index & 0.01594 & 0.01790 & 0.02231 & 0.02623 & 0.01722 & 0.01956 \\
\hline \multirow[t]{3}{*}{ FB\&H } & Headcount index & 0.18529 & 0.16539 & 0.17875 & 0.18006 & 0.18398 & 0.16832 \\
\hline & Poverty gap index & 0.04722 & 0.04080 & 0.04151 & 0.05011 & 0.04608 & 0.04266 \\
\hline & Poverty severity index & 0.01789 & 0.01540 & 0.02076 & 0.02505 & 0.01847 & 0.01733 \\
\hline \multirow[t]{3}{*}{$\mathrm{RS}$} & Headcount index & 0.17879 & 0.20276 & 0.22671 & 0.23758 & 0.18837 & 0.20972 \\
\hline & Poverty gap index & 0.03835 & 0.05455 & 0.05015 & 0.05730 & 0.04071 & 0.05510 \\
\hline & Poverty severity index & 0.01329 & 0.02207 & 0.02508 & 0.02865 & 0.01565 & 0.02339 \\
\hline \multirow[t]{3}{*}{ BD } & Headcount index & 0.09555 & 0.26064 & 0.19689 & 0.20938 & 0.11582 & 0.25039 \\
\hline & Poverty gap index & 0.01464 & 0.06782 & 0.03816 & 0.04297 & 0.01934 & 0.06285 \\
\hline & Poverty severity index & 0.00389 & 0.02465 & 0.01908 & 0.02148 & 0.00693 & 0.02402 \\
\hline
\end{tabular}

Source: Author's calculations based on HBS 2004 and HBS 2007 databases

Based on the values of poverty indices, presented in Table 4, the general conclusion is that the state of poverty in Bosnia and Herzegovina and its constituent parts was worse in 2007 than in 2004.

In fact, only in FB\&H, poverty measured by headcount index, poverty gap index and poverty severity index (based on consumption) decreased in 2007 compared to 2004. In the $\mathrm{RS}$ and $\mathrm{BD}$, poverty rate measured by consumption increased significantly, as well as its depth

14 There were not data on psychological and social dimensions of deprivation, in the used databases. Variables related to social and psychological component of living in Bosnia and Herzegovina are planned in the next wave of Household Budget Survey.

15 Cases when calculated index in 2007 was higher than in 2004 i.e. the state of poverty in 2007 worse than in 2004, are bolded. 16 The results are generated by SPSS 17.0, CSPSS Inc., 2010. 
and severity. As a result of these changes, at the level of entire $B \& H$, there was a slight decline in poverty from $18.12 \%$ to $18.02 \%$, but its depth and strength increased, as is evident from poverty gap index and poverty severity index.

In the case of educational poverty, the situation is worse in all segments in 2007 than in 2004. In B\&H in general, and in FB\&H, RS and Brcko District, the rate of educational poverty, its depth and strength have increased.

Two-dimensional headcount index, poverty gap index and poverty severity index, which contain the results of one-dimensional indices, also show an increase in rate, depth and strength of poverty in the case of combining the consumption and education. Only in FB\&H the two-dimensional poverty declined, as a result of greater weight (0.8) assigned to consumption compared to weight (0.2) assigned to education.

\section{CONCLUSION}

The investigation of poverty in terms of its multidimensionality is an imperative in modern studies and poverty analysis. It is expected that the researches in this field have to find operational ways for the selection, calculation and analysis of the multidimensional indicators of poverty.

Poverty is measured and analyzed through a variety of available monetary and nonmonetary measures of poverty / welfare, such as income, consumption, education, health, standard of living, housing conditions, social inclusion and many other measures. This paper provides an assessment of poverty in Bosnia and Herzegovina based on consumption, education and deprivation.

An analysis of poverty based on consumption and deprivation was performed at the level of entire Bosnia and Herzegovina and its constituent parts and was based on the onedimensional and two-dimensional Foster-Greer-Thorbecke's poverty indices. It was concluded that, in most of the country, poverty rate measured by consumption is greater than poverty rate measured by deprivation, but its depth and strength are lower when measured by consumption than by deprivation. Therefore, although poverty measured by consumption included a larger percentage of the population, it is less severe and more homogeneous than poverty measured by deprivation. It seems that population in Bosnia and Herzegovina is not poor to the point obtained by estimates based on consumption. Reasons for that situation probably lie in family transfers from abroad, covering actual consumption in order to avoid taxes, the underground economy etc.

One-dimensional and two-dimensional Foster-Greer-Thorbecke's poverty indices were calculated and analyzed based on consumption and education. Indices were determined for entire Bosnia and Herzegovina and separately for its constituent parts. We have compared the state of one-dimensional and two-dimensional poverty in 2004 and 2005 for all examined areas.

The analysis showed that only in FB\&H, poverty rate measured by consumption, its depth and strength decreased in 2007 compared to 2004. At the level of entire B\&H the poverty 
rates were approximately equal. At the other levels (RS and BD), the poverty rates measured by consumption, its depth and strength were significantly increased in 2007 compared to 2004. In the case of the educational poverty, at the level of the entire B\&H and its constituent parts, the rate of educational poverty, its depth and intensity were higher in 2007 than in 2004.

Two-dimensional poverty indices, based on consumption and education, reflect the behavior and values of one-dimensional indices, in accordance with the assigned weights. These indices also show that, except in the case of FB\&H, two-dimensional poverty, measured by consumption and education, increased in terms of poverty rate and its depth and intensity. This situation reflects increased unemployment rate, increased education costs, distance of the schools in rural areas and inadequate government response in address these issues.

In order to monitor changes in the state of poverty in Bosnia and Herzegovina, it is desirable to determine the same indices based on the new data, in further analysis of multidimensional poverty in the country. It would also be useful to introduce other, nonmonetary measures of poverty/welfare, which could reflect the social and psychological dimensions of poverty and especially social inclusion issues. After completion of the third wave of the survey, is expected to estimate the impact of the economic crisis and reduced economic activity at the calculated measures of poverty and living standard in the country. It will be significant help to the government in an effort to reduce poverty and adjustment measures for the protection of vulnerable population groups.

\section{REFERENCES}

Antony, G. M., Visweswara Rao, K., (2007), "A composite index to explain variation in poverty, health, nutritional status and standard of living: Use of multivariate statistical methods", Public Health, 121 (Issue 8): 578 - 587

Ayala, L., Jurado, A., Perez-Mayo, J., (2009), "Income Poverty and Multidimensional Deprivation: Lessons from Cross-Regional Analysis", ECINEQ-Society for the Study of Economis Inequality, Working Paper No. 106

Bibi, S., (2005)," Measuring Poverty in a Multidimensional Perspective: A Review of Literature", PEP-PMMA Working Paper No. 2005-07

Bourguignon, F., Chakravarty, S. R., (2003), "The measurement of multidimensional poverty", Journal of Economics Inequality, 1 (Issue 1): 25 - 49

Brozek, B., (2005), Siromaštvo i ekonomija, (Sarajevo:Ceteor)

Danziger, S. H., Haveman, R.H., (2002), Understanding Poverty, (Cambridge: Harvard University Press, New York: Russell Sage Foundation)

Dekkers, G. J. M., (2008), "Are you unhappy? Then you are poor! Multi-dimensional poverty in Begium", International Journal of Sociology and Social Policy, 28 (11/12): 502 - 515

Kakwani, N., Silber, J., (2008), Quantitative Approaches to Multidimensional Poverty Measurement, (New York: Palgrave Macmillan)

Khandker, S. R., Haughton, J., (2009), Handbook on Poverty and Inequality, (Washington DC: World Bank Publications) 
Payne, R. K., (2005), A Framework for Understanding Poverty, (Highlands: aha Process, Inc.)

Ravallion, M., (1992), "Poverty Comparisons: A Guide to Concepts and Methods”, World Bank Living Standarad Measurements, Working Paper No. 88.

Silber, J., (2007), “Measuring Poverty: Taking a Multidimensional Perspective", Hacienda Publica Espanola, 182 (3): 29 - 74

Sen, A., (1982), Poverty and Famines, (New York: Oxford University Press)

Wagle, U., (2008), Multidimensional Poverty Measurement, (New York: Springer)

Wagle, U., R., (2008), "Multidimensional Poverty: An Alternative Measurement Approach for the United States", Social Science Research, 37 (Issue 2): 559 - 580

*** "Anketa o potrošnji kućanstava u BiH 2007: Siromaštvo i uvjeti života", (2008) Agencija za statistiku Bosne i Hercegovne, (Sarajevo)

*** "Anketa o potrošnji kućanstava u BiH 2007: Konačni rezultati", (2008), Agencija za statistiku Bosne i Hercegovne, (Sarajevo)

*** "Anketa o potrošnji domaćinstava u BiH 2004: Konačni rezultati", (2005), Agencija za statistiku Bosne i Hercegovine, (Sarajevo)

*** "Anketa o mjerenju životnog standarda u Bosni i Hercegovini", (2001), Agencija za statistiku Bosne i Hercegovine, (Sarajevo)

*** “Bosnia and Herzegovina: Poverty Assessment, Volume I: Main Report”, (2003), Document of the World Bank

*** “Bosnia and Herzegovina: Poverty Assessment, Volume II: Data on Poverty", (2003), Document of the World Bank

*** Coudouel, A., Hentschel, J. S., Wodon, Q. T., (2002), "Poverty measurement and analysis", Poverty Reduction Strategies and PRSPs, PovertyNet, World Bank

\section{MULTIDIMENZIONALNI ASPEKTI SIROMAŠTVA U BOSNI I HERCEGOVINI}

\section{SAŽETAK}

Ovaj članak se bavi istraživanjem mogućnosti za proširivanje postojećih standardnih analiza siromaštva u Bosni i Hercegovini, baziranih na monetarnim mjerama siromaštva/ blagostanja. Istraživanjem dostupnih ranijih studija i odgovarajućih baza podataka ustanovljeno je da je moguće kreirati nove, nemonetarne mjere siromaštva koje mogu poslužiti pri određivanju multidimenzionalnih indikatora siromaštva. U radu se predlažu dvije nove nemonetarne mjere siromaštva: obrazovanje $i$ deprivacija, koje doprinose preciznijoj procjeni stanja $i$ analizi siromaštva u zemlji. Na osnovu izračunatih novih indikatora siromaštva, baziranih na potrošnji, obrazovanju i deprivaciji, izvedeni su zaključci o stanju siromaštva u zemlji te date preporuke za buduća istraživanja.

Ključne riječi: multidimenzionalni indikatori siromaštva, siromaštvo, Foster-GreerThorbecke-ovi indeksi, deprivacija, obrazovno siromaštvo 